\title{
DEMOBILISATION AND THE POST-WAR EMPLOYMENT OF THE WHITE UNION DEFENCE FORCES SOLDIER
}

\author{
François Oosthuizen*
}

Following the end of the Second World War, the Union Government regarded the provision of employment as the most important demobilisation benefit to which ex-UDF volunteers were entitled. It had been laid down as a matter of policy that no volunteer would be discharged until he had been offered "suitable employment". This was defined as employment under conditions no less favourable than those existing at the time of leaving his or her previous employment in order to enlist.

It was recognised that the re-employment of the very large number of men and women demobilised from the armed forces would be one of the most serious problems facing the government, employers' and workers' organisations, during the transition from war to peace. ${ }^{2}$ The Rand Daily Mail of 27 August 1945, stated that demobilisation would be an even greater prob-

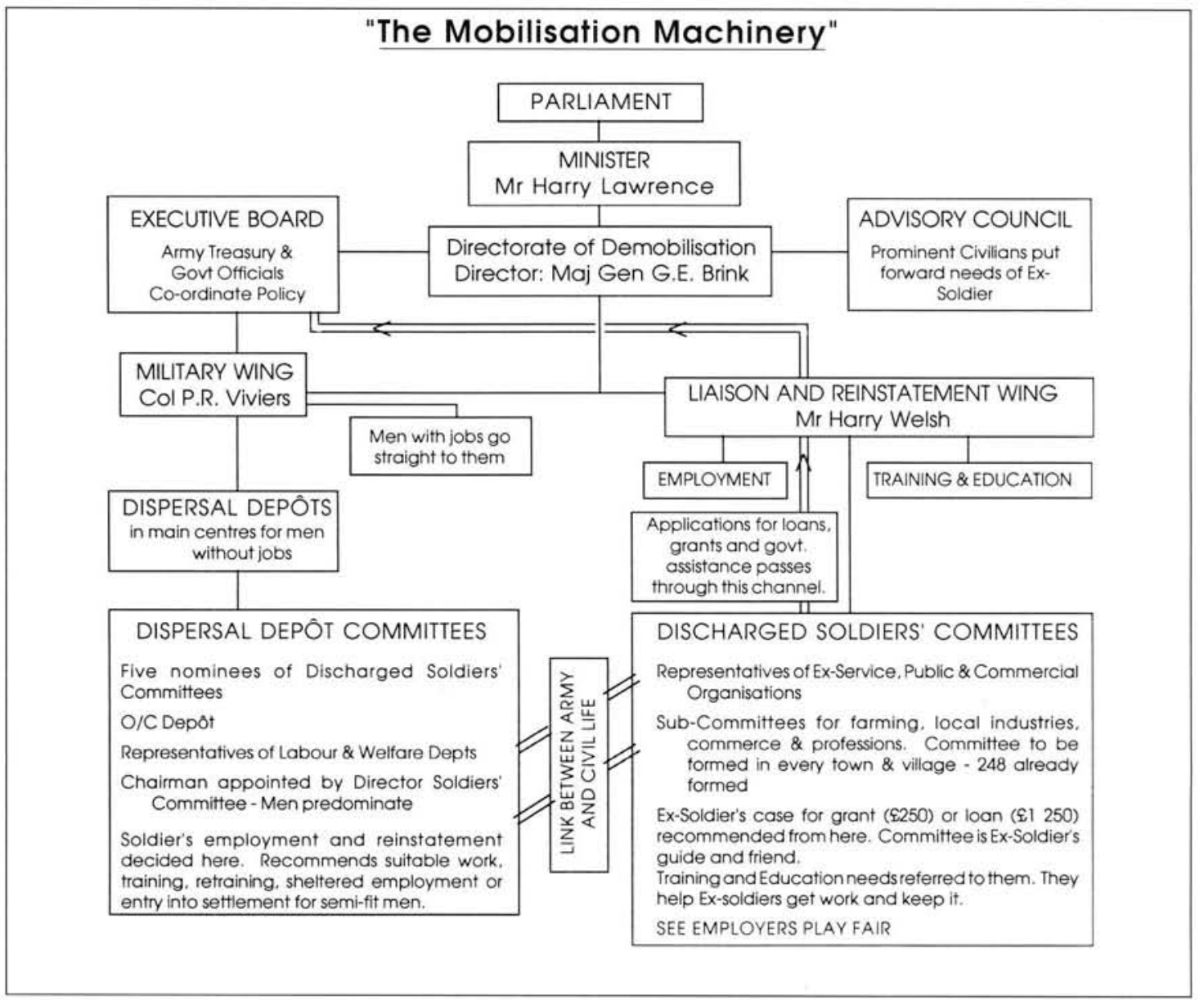

Source : Directorate of Demobilisation Booklet, The Demobilisation Machine

Directorate Documentation Service, Pretoria. Archives of the Union War Histories (hereafter UWH Civil), Box 94 , A brief progress report for the period ending 31 Junly 1945 by the Information and Intelligence Section, 1 August 1945, p. 4. (See also DC, Box 3581. DSDC Circular No. 14, 8 February 1945.)

2 D.C. Tait: "Veteran re-employment plans for the Allies", in The Annals of the American Academy of Political and Social Science, p. 103. 
lem than mobilisation had been at the start of the war. ${ }^{3}$ This was due to the absence of the drive and excitement of war, as well as a shortage of capital which gave rise to concern.

D.C. Tait identified four important aspects to be considered by the Allied forces in their respective post-war reemployment plans, which were clearly reflected in the principles adopted by the Smuts government. The aspects included the gathering of information by means of a questionnaire, the reinstatement of ex-soldiers in their pre-war employment, preference to ex-soldiers in respect to Government employment, and the establishment of the order of demobilisation, giving preference to military considerations. ${ }^{4}$ These principles were adopted in all the Allied countries, although the detailed application thereof, which are of particular importance to this study, showed great variety.

In order to execute this four-pillared demobilisation plan, sections were set up within the Directorate of Demobilisation for the co-ordination of information on government and non-government employment. ${ }^{5}$ Questionnaires were sent to employers and to all members of the UDF, except the Native Military Corps (NMC). The purpose of the questionnaire was, firstly, to determine the number of volunteers having employment to return to; secondly, those without any employment whatsoever; and, thirdly, the number of servicemen in need of training or retraining in order to be able to establish themselves in civilian life. ${ }^{6}$

This survey revealed 46475 men and 9615 women required employment. By August 1945, 20944 vacancies existed for white men and 11555 for women? Although it seemed as if adequate employment opportunities would be pro- vided for women, more vacancies were still needed for the men.

Parliament, furthermore, adopted two laws to ensure that volunteers were reinstated in their pre-war jobs. These were the Public Servants Act (No 27 of 1944) and the Act on Civil Servants (No 40 of 1944). ${ }^{8}$ Both laws were meant to prevent discrimination against the exvolunteer who had to give up his employment in order to join the war effort. ${ }^{9}$ The Public Servants Act determined that the ex-volunteer had to be reinstated within his pre-war job, if he had enlisted with the knowledge of his or her employer. The Act on Civil Servants determined that an ex-volunteer, resuming his job in the civil service, would not lose any service benefits as a result of his military service. ${ }^{10}$

In order to qualify for these benefits, the soldier had to apply for his job within six months of discharge. ${ }^{11}$ In comparison with the United Kingdom. where ex-soldiers had to apply for employment within five weeks of discharge, this aspect seemed to be a unique feature of the South African demobilisation scheme and seemed more generous than the employment provisions of any other country. ${ }^{12}$

Hereby, the government ensured that the ex-volunteer was employed for a minimum period of twelve months and also safeguarded their interests by forcing employers to reinstate the exsoldier in a job under conditions not less favourable than those existing when their employees enlisted. Ex-soldiers were to be redeployed without reduction in pay and could not be dismissed. If the ex-soldier went on a training or retraining course, the period of protection was extended by the time spent on the course. ${ }^{13}$

The government not only set an exam-

\footnotetext{
Rand Daily Mail, 27 August 1945.

D.C. Tait : Veteran re-employment plans for our Allies", The Annals of the American Academy of Political and Social Science, pp. $103-106$.

UWH Civil, Box 94, Demobilisation Statement by the Minister of Welfare and Demobilisation, p. 28. Ibid.

UWH Civil, Box 43, Demobilisation Contact Letter No. 9, 31 August 1945.

Directorate Documentation Service, Pamphlets, No. 3501, Box 185, pp. 11 - 12.

Ibid. (See also AG (3), 154, Box 78, Demobilisation: Reinstatement of the Volunteer, 24 September 1945, p. 11.)

lbid.

Ibid.

Ibid. (See also DC, Box 3355, File DC 2214/6, Further comparison of benefits)

$A G$ (3), 154, Box 78, Demobilisation: Reinstatement of the Volunteer, 24 September 1945, pp. 13 -14.
} 
ple in the preference given to ex-soldiers, but also in the provision of employment. Volunteers with no employment to return to, were retained on military strength with full pay and allowances until suitable employment could be found. If the ex-soldier lost the employment through no fault of his own within a year, he could also return to the army until another suitable position was found. Should the ex-soldier lose his second job through his own fault, he was taken back on reduced rates for a maximum of 120 days. Those refusing employment which was considered to be suitable were retained on a reduced scale of allowances for a maximum of only four months. ${ }^{14}$

The third important principle, that relating to job preference and job reservation. was a thorny one. Many felt that it would not be possible to draft a general preference scheme that would operate fairly in practice. some took the view that it might be used to foster antagonism between ex-soldiers

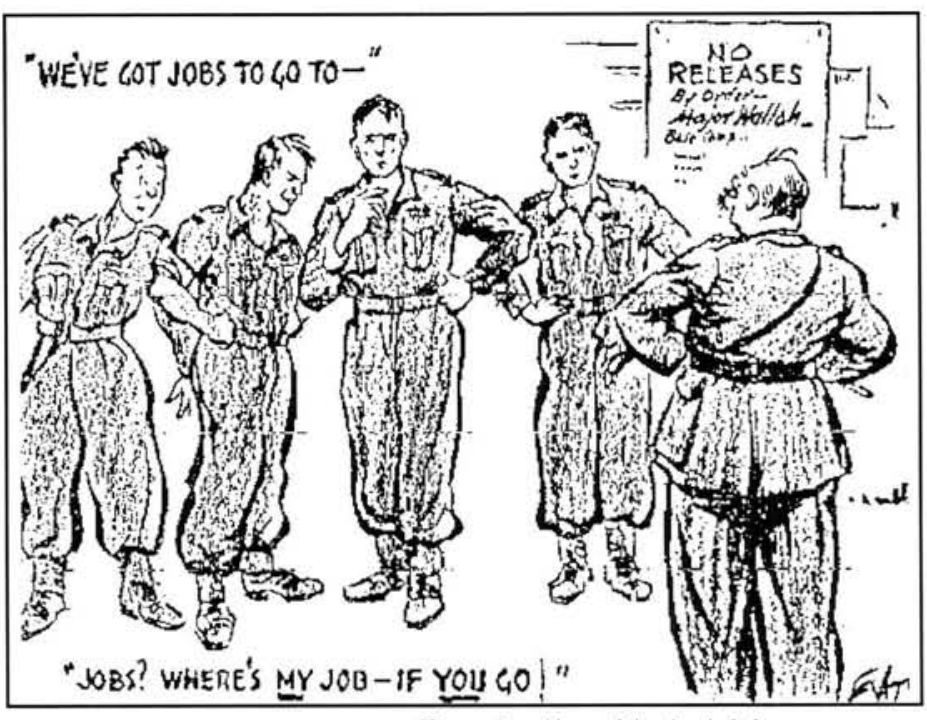

- Evo in the Natal Mercury Source: The Forum, 7/7/45 ment afford the ex-soldier the opportunity to be completely and satisfactorily reinstated in civilian life. ${ }^{17}$ No person other than an ex-soldier could be appointed to a post, unless the Department of Labour could provide a certificate confirming that no suitable ex-soldier was available for the post in question. ${ }^{18}$

The Government's commitment to full post-war employment for all ex-soldiers was further illustrated by the various state departments working long hours and by the fact that workers were employed on a temporary basis in order to reserve vacancies for returning soldiers. ${ }^{19}$ The government also aimed to set an example to other employers with regard to the provision of employment. In order to achieve this, government employment was taken care of by the Directorate of Demobilisation and aimed to establish and main- and other workers or non-volunteers. ${ }^{15}$ It created the possibility that ex-soldiers might receive preference above a civilian worker, despite the fact that the exsoldier had less experience. Nevertheless employers were requested by the Government to give preference to unemployed ex-volunteers, and had to ensure that the employment was commensurate with the ex-soldier's war experience, abilities and qualifications. ${ }^{16}$ The main aim being that the employ- tain personal contacts with all Government Departments, Administration and Boards, and to gather information concerning proposed Government schemes, works and services. ${ }^{20}$

In a demobilisation contact letter, dated 30 May 1945, the Government announced that there were $11201 \mathrm{va}$ cancies in various government departments including the South African Police, the Department of Posts and Tel-

6 Archives of the Secretary for Defence (DC), Box 3581, DSDC Circular No. 14: Employment - The Policy of Government. 8 February 1945

17 Ibid.

18 UWH Civil, Box 94, Demobilisation statement by the Minister of Welfare and Demobilisation, pp. 11-12.

19 DC, Box 3581, Demobilisation statement by the Minister of Welfare and Demobilisation. The United Kingdom similarly tried to reduce unemployment to a minimum by an orderly process of releases adjusted to the speed of the reconversion of war industries. Thus, the U.K. in its whole demobilisation effort did not focus only on demobilisation, but on the relocation of manpower. ( $A G(3)$, Box 28, File $A G(3) 404 / 1$. Demobilisation in Britain. 1 May 1947, p. 2.)

20 UWH Civil, Box 43. Demobilisation contact letter No. 9, 31 August 1945
} 
egraphs and the South African Railways and Harbours. ${ }^{21}$ It was clear that the Government was safeguarding the interests of the Public Sector and the Railway employees, but they were also creating the machinery for opening doors of the other Government Services to some thousands of other ex-soldiers.

The fourth principle that the Government had to consider was the priority and the order of the discharge of the soldiers. Priority was determined by the length of service in the UDF. The basic principle was "First in, first out" (FIFO) ${ }^{22}$ All the members of the UDF were classified in groups ranging from Group A with attestation dates between September 1939 and 30 April 1940 to Group $M$ with attestation dates from 1 January 1945 onwards. White men and women, the Cape Corps and Indian and Malay Corps, and the Native Military Corps were grouped separately. ${ }^{23}$ Demobilisation took place on an individual basis rather than a unit basis since the whole dispersal depot machinery, which was built up during the war, was based on a system of individual discharges.

Military personnel within the Union were considered for demobilisation first, with the exception of those personnel serving in certain key positions and those whose demobilisation depended on the complete demobilisation of personnel from other theatres of war. ${ }^{24}$ The second stage commenced on the arrival of troops from areas elsewhere in Africa; and the final stage was reached on return of troops from other operations, those held P.O.W. and those on duties in enemy territory. ${ }^{25}$

Furthermore, the Directorate adopted a policy which entailed that no volunteer would be given assistance to change his pre-war occupation. This step was criticised as being unnecessarily harsh. It was pointed out by the ex-soldiers that, had they not joined the service, they would probably have changed their occupations for better ones in the normal course of events. The exceptions under which the government service could be invoked, gave an unfair advantage to the soldiers in the service who may have acquired skills and trades during the course of their duties, as against the combatant who had no such opportunities. ${ }^{26}$ On the other hand, one could question the possibility of the war experience really having such a beneficial and continuous effect on the soldier and his reinstatement in a post-war occupation. Was the army's primary task not that of a war machine geared to accomplish victory in the short term? Surely more intensive training was needed if the education and skills obtained in the army were to be of a lasting and beneficial nature. ${ }^{27}$ One cannot, however, disregard the soldiers' exposure to the different facets of army life.

The government's position concerning re-employment can best be summarised in the words of Mr Welsh, Chairman of the Liaison and Reinstatement Wing, who stated: "We, in our job, will be motivated by idealism, our job is to see that the promises made to ex-soldiers are carried out to the letter. If we do this there will be no such an expression as 'forgotten men'." 28

However, was the government able to fulfil the promises made to the ex-soldier regarding post-war employment? Or were there 'forgotten men'?

From the aforementioned analysis of the demobilisation principles adopted by the Government concerning postwar employment, it seemed as if the Government was under the impression

\footnotetext{
21 UWH Civil, Box 43, Demobilisation and contact letter No. 7, 30 May 1945.

$A G(3)$, Box 47, Aspects of Demobilisation, p. 2

Ibid. 24 AG(3), 154, Box 565, File AG(3), 154/203/39, Memo by the Civil Re-employment Board on Demobilisation Regulation,
pp. 1-2.

25 Ibid.

26 UWH Civil, Box 94: Reporton the soldiers' reception of the Governments demobilisation and rehabilitation plans, 11 July 1944,p. 1.

27 Compare the article of L.W.F. Grundlingh: "Soldiers and Politics: A Study of the political consciousness of Black South African soldiers during and after the Second World War". Historia, 36(2). November 1991. 28 Archives of the General Officer Commanding. Union Defence Forces (UDF), Box 120, File: 826/1/7/A Vol. 1, Contact
letter of the Director-General of Demobilisation No. 8, 30/5/45.
} 
that the combination of liberal demobilisation benefits (gratuities, clothing allowance and financial assistance) and the emphasis on secured re-employment was an almost ideal situation for the reabsorption into civilian life of the thousands of soldiers, who had laid down their arms after the cessation of hostilities. However, it soon became clear that the Government's policy to-
K.J. Gibbs states that the South African economy was not ready to receive the ex-soldiers. The post-war difficulties in acquiring new machinery, and raw material due to shipping problems, prevented industrial expansion which was necessary to provide employment opportunities. ${ }^{29}$ In this regard the Union differed significantly from the demobilisation approach adopted by the

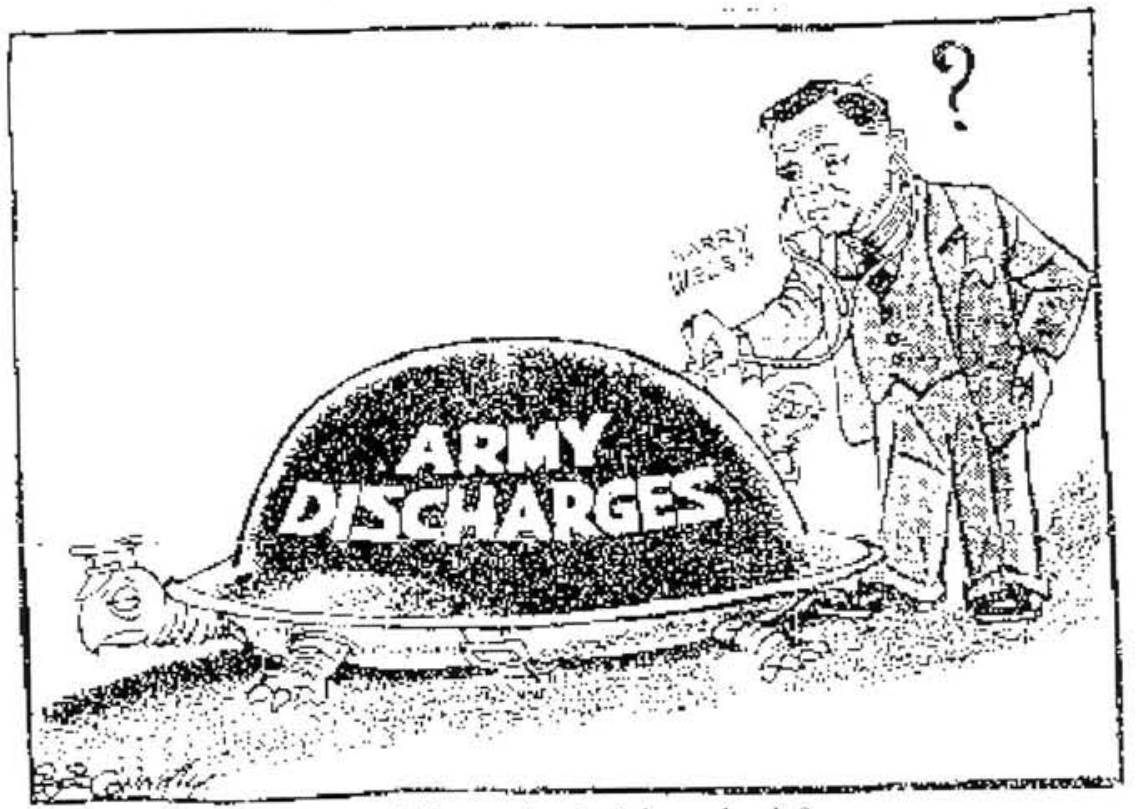

What makes it tick so slowly?

wards post-war employment for the exsoldiers was worlds apart from the way the soldiers experienced it at first hand on their return to the Union.

The general economic situation in the Union played the important role in the provision of post-war employment. The Depression of the Thirties was not forgotten and many soldiers feared a repetition of the Depression years. The soldiers also knew that a depression occurred soon after the last war. This realisation heightened the anxiety of some of the soldiers who had to return to a civilian occupation, especially those who never had a job before the war, those in poorly paid jobs, those who had built up a job before the war and had to start all over again, and those who feared that they had forgotten their skills. Despite the soldiers' fears, the Government, none the less, committed itself to ensuring employment to all the returning soldiers.
United Kingdom. In the United Kingdom the post-war reconstruction did not emphasise demobilisation as such. but rather the reallocation of manpower. This was achieved by controlling the discharges of soldiers in accordance with the conversion from war to peace-time industries, thus ensuring that the soldiers that were demobilised. immediately had employment to return to. ${ }^{30}$

In practice, however, some of the exsoldiers did experience difficulties in finding employment. This was mainly due to the delays in the demobilisation process caused by three factors. Firstly, the Directorate experienced organisational difficulties due to shortages of staff and accommodation. This resulted in delays in the processing of discharges. With the establishment of the Directorate on 1 April 1944, 231090 soldiers still had to be demobilised. ${ }^{31}$ Only 214 Union Defence Forces and Wo-

$A G(3), 154$, Box 28, File $A G(3) 154 / 365 / 25 \mathrm{Vol}$. 10. Appreciation of the demobilisation problem. 31 March 1946. 
men's Auxiliary Defence Corps officers and other ranks were, however, allotted to the Directorate to process the discharges. ${ }^{32}$ One can therefore understand why the Natal Mercury reported that "It would be an exaggeration to say that the welfare of the men is something Defence is not concerned with, but where the welfare of the soldier and the regulation clash, the regulations come first". ${ }^{33}$ Some of the exsoldiers were extremely annoyed about the personnel shortages and felt that the staff shortages should have been dealt with earlier.

The second reason concerned delays in the repatriation process. Problems relating to the reconversion of aircraft to passenger planes, shortages in finding fuel and a general lack of shipping space, created problems in the repatriation of soldiers from overseas. $^{34}$ Some of the soldiers were of the opinion that the whole situation was pretty shocking and some described the air evacuation scheme as a complete failure. Some soldiers even questioned the sincerity of the government's promise of a speedy return and their smooth reinstatement into civilian life.

Thirdly, changes in the official discharge policy led to a severe criticism and delays in finding suitable post-war employment. Initially, the discharges were to take place on a FIFO basis according to the soldier's date of attestation. However, this changed when the military authorities discovered that practically all $A$ and $B$ groups consisted of officers and NCO's; and decided to adopt a ratio scheme of 3 officers, 14 NCO's and 18 other ranks to be discharged in that order. Consequently, privates were released before officers who had a longer service record. This led to widespread criticism. The soldiers felt that those who were most likely to be prejudiced by their return to civilian life being postponed, should receive priority. For example students to be demobilised at the beginning of the academic year as well as professional men and farmers who had their own business and were not salaried. From the discussion it was clear that the soldiers demanded that those who had work to return to be demobilised quickly. The soldiers for instance suggested that those with employment waiting should not have to call at a Dispersal Depot to obtain discharge papers.35 These demands were indicative of the soldiers' eagerness to get home quickly. Even the Minister of Welfare and Demobilisation expressed the hope that the soldiers return to civilian life would

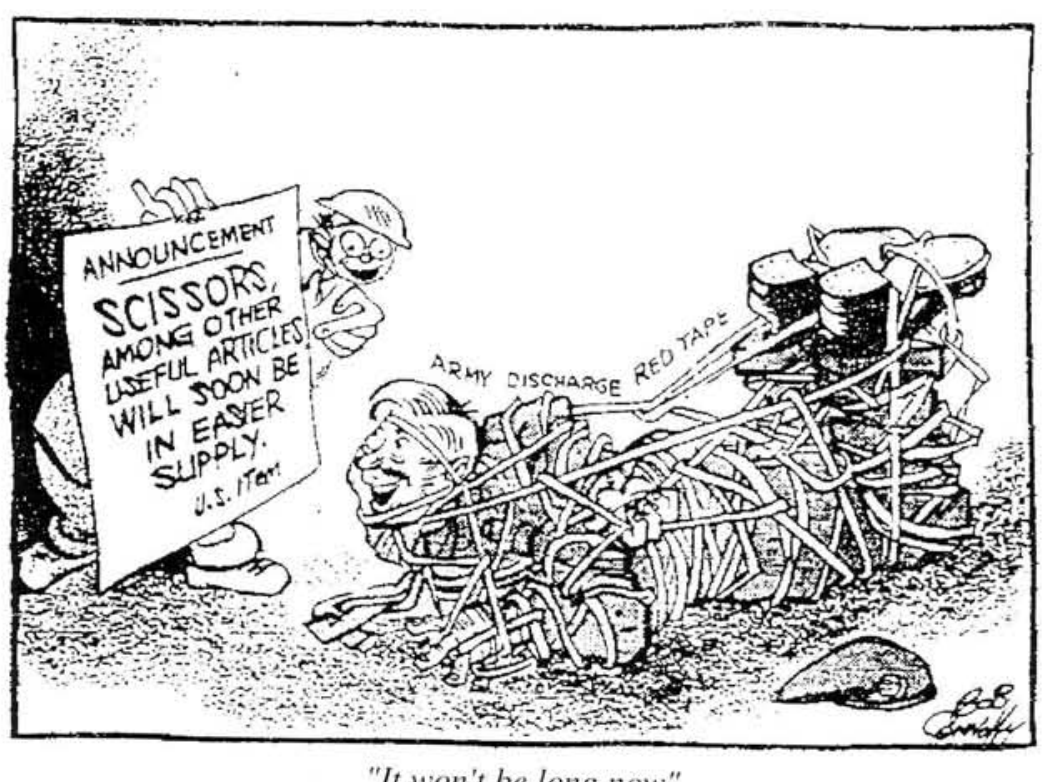

Sources, Appendices D and E: Connoly, B.: Victory Cartoonnews-Selection of Rand Daily Mail Cartoons. CNA, Johannesburg, 1945.

\footnotetext{
Ibid.

Report quoted in the Rand Daily Mail, 3 October 1945.

Rand Daily Mail, 3 October 1945.

AG(3), 154,Box 483, File AG(3) 154/365/11, 10 March 1945.

The Star, 11 August 1945.
}

\section{be speeded up.}

A soldier remarked that the demobilisation scheme was not being run according to the original promises. A warrant officer described the ration scheme as "anything but fair". ${ }^{36}$ The Authorities' explanation was that they had to maintain discipline, and that the ration scheme was the best way of ensuring it. Consequently, the problems relating 
to the organisational difficulties of the Directorate resulted in the unnecessary retention of ex-soldiers who had employment to return to.

In the Rand Daily Mail of 5 January 1945, the UDF refuted all allegations and stated that soldiers were retained on strength only in the national interest and that they were merely adhering to the discharge policy. ${ }^{37}$ The retention on the one hand, had the innate possibility of being politicised; while on the other hand, the Government was contributing to the skilled manpower shortage experienced by industry. Commerce and industry repeatedly requested that technical and skilled labour be discharged so as to create more employment opportunities. ${ }^{38}$

Other problems relating to post-war employment mainly concerned those ex-soldiers who were unemployed prior to the war. The Military experience did not improve their prospects of employment, and some of them had little incentive to find employment at all. Many of them lived at the expense of the Defence Department. This was the result of a provision made in the demobilisation plan that soldiers not finding employment, be retained on military strength. ${ }^{39}$

Problems in finding employment were not only restricted to economic factors and organisational difficulties, but was also influenced by politics. Some of the ex-soldiers experienced problems in returning to their pre-war employment. The Nationalist Brakpan Town Council, for instance, adopted a policy to the effect that all men and women serving in the Forces were barred from applying for any position which became vacant during the war. The same occurred in Pretoria and Bloemfontein. This, despite the fact that state departments were requested to fill all vacancies temporarily. The Springbok Legion severely criticised the step and described the political nature of the event as "a living example of what the promises of the anti-war opposition amounted to". ${ }^{40}$

The securing of post-war employment to the ex-soldier was the cornerstone of the whole demobilisation plan and the Smuts government's attempt to secure employment for a great many volunteers, was admirable. On the other hand, the government did not take into account the broader political, economic and social issues that influenced the promises they had made to the ex-soldiers. New signs of unemployment were already evident by 1948, when nearly 4000 whites were reported to be unemployed. ${ }^{41}$ This could possibly have been prevented if a more controlled discharge procedure had been followed, which took into account the industries progress in their reconversion from a war to a peacetime footing. This indicates that the real problems had only been solved temporarily. Thus, it seems as if the Union Government found it extremely difficult to implement its idealistic fine paper plans concerning the post-war employment of the UDF soldier, in the aftermath of the Second World War.

*François Oosthuizen is attached to the Department of History, Vista University.

37 Rand Daily Mail, 5 January, 1946.

38 $A G(3), 154$, Box 484, File AG(3) 154/364/11, Vol 3: Letter from the Johannesburg Chamber of Commerce and Industry, 14December 1945.

39 K.J. Gibbs: Demobilisation after World War II, p. 31.

40 Pamphlet distributed by the Springbok Legion entitled: "Victimisation of Ex-Volunteers", Brakpan Town Council.

41 Bureau of Census and Statistics, Union Statistics for Fifty Years, p. G-16. 